Article

\title{
Techno-Economic Feasibility of a Grid-Connected Hybrid Renewable Energy System for a School in North-West Indonesia
}

\author{
Biadelma Illiandi ${ }^{1}$, Abhishek Tiwary ${ }^{2, *}$ \\ 1 Fatih Bilingual School, Sultan Malikul Saleh, No. 103, Bandaraya, Lamlagang, \\ Lam Lagang, Banda Raya, Banda Aceh City, Aceh 23122, Indonesia \\ 2 School of Engineering and Sustainable Development, De Montfort University, \\ Leicester, LE1 9BH, UK \\ * Correspondence: Abhishek Tiwary, Email: abhishek.tiwary@dmu.ac.uk.
}

\begin{abstract}
Background: Schools typically have high diurnal fluctuation in electricity demand, with peak loads during daylight hours, which could be adequately met through harnessing solar renewable resources. This study demonstrates the strength of techno-economic assessment in selection and optimization of a grid-connected hybrid renewable energy system (HRES), utilizing local renewable resources to fulfil the daytime electricity demand for a school in northwest Indonesia.
\end{abstract}

Methods: Three different scenarios are developed for optimizing the HRES configurations, comprising of PV panels, Wind turbine, Battery and Inverter. The following optimization parameters are used-one, technological performance of the HRES, in terms of their energy output to fulfil the energy deficit; two, economic performance of the HRES, in terms of their net present cost (NPC) and payback periods.

Results: A clear trade-off is noted between the level of complexity of the three HRES, their renewable electricity generation potentials, NPC and payback periods. Scenario II, comprising of Solar PV and Inverter only, is found to be the most feasible and cost-effective HRES, with the optimized configuration of $245 \mathrm{~kW}$ PV capacity and $184 \mathrm{~kW}$ inverter having the lowest initial capital cost of US\$ 51,686 and a payback time of 4 years to

\section{Open Access}

Received: 07 November 2019

Accepted: 14 March 2020

Published: 18 March 2020

Copyright $\odot 2020$ by the author(s). Licensee Hapres, London, United Kingdom. This is an open access article distributed under the terms and conditions of Creative Commons Attribution 4.0 International License. meet the school's annual electricity load of $114,654 \mathrm{kWh}$. Its NPC is US\$ $-138,017$ at the 20th year of installation. The negative value in year 20 is achieved through the sale of $40 \%$ of the renewable energy back to the grid.

Conclusions: Techno-economic assessment can provide useful decision support in designing HRES relying on solar energy to serve predominantly daytime school electricity requirements in tropical countries.

KEYWORDS: grid-connected; HRES; NPC; payback; school; technoeconomic 


\section{INTRODUCTION}

The Indonesian government has set target to sustainably harness energy by increasing the share of new and renewable resources in primary energy supply to reach $23 \%$ by 2025 and $31 \%$ by 2050 [1,2]. However, while the last decade has seen rapid growth in renewable energy generation in many parts of the world [3], the grid supply in Indonesia, and more widely in South-east Asia, still heavily relies on conventional fossil-based electricity generation [1,4]. The majority of the Indonesian people are still not fully aware of the bountiful solar resources which can be harnessed for sustainable energy generation [5]. This is contradictory to the fact that increased heat stress among the local population has reduced the Indonesian annual GDP by $6 \%$, attributed mainly to physiological impacts and reduced labor productivity owing to its close proximity to the Equator [6].

The statistical data of the state-owned electricity company of Indonesia shows that in 2016 only $12.16 \%$ of the overall electricity was generated from renewable energy sources, of which the majority was from hydro and geothermal energy [7]. Solar and wind power in total only contribute to mere $0.02 \%$ of the entire electricity generation, despite having an average daily solar radiation of $4.80 \mathrm{kWh} / \mathrm{m}^{2}$ [8]. However, only $0.038 \%$ of this resource is converted into electrical energy at the moment. The typical average wind speed in the country ranges between 3 and $6 \mathrm{~m} / \mathrm{s}$, however, only $0.005 \%$ of this resource was used into the national energy mix in 2016 (Table 1) [9].

Table 1. Renewable energy resource utilization potential in Indonesia [9].

\begin{tabular}{cccc}
\hline Energy Source & Resources & Installed Capacity & Utilization (\%) \\
\hline Hydro & $94,476 \mathrm{MW}$ & $5024 \mathrm{MW}$ & $5.30 \%$ \\
Geothermal & $29,544 \mathrm{MW}$ & $1403.5 \mathrm{MW}$ & $4.80 \%$ \\
Bioenergy & $32,000 \mathrm{MW}$ & $1740.4 \mathrm{MW}$ & $5.40 \%$ \\
Solar & $4.80 \mathrm{kWh} / \mathrm{m}^{2} / \mathrm{day}$ & $78.5 \mathrm{MW}$ & $0.038 \%$ \\
Wind & $3-6 \mathrm{~m} / \mathrm{s}$ & $3.1 \mathrm{MW}$ & $0.005 \%$ \\
Marine and Tidal & $61 \mathrm{GW}$ & $3.1 \mathrm{MW}$ & $0.005 \%$ \\
\hline
\end{tabular}

Aceh is the most westerly province of the Indonesian archipelago. According to the Indonesian Renewable Energy Department of Mining and Energy this province has the potential for geothermal, wind, hydro, solar and wind power of $340 \mathrm{MW}, 6600 \mathrm{MW}, 7881 \mathrm{MW}$ and 894 MW respectively [10]. This makes a hybrid renewable energy system (HRES) a viable solution for generation of electrical energy in maximizing the electricity production while minimizing the consumption of fossil fuel [11].

Schools, having their activities largely limited to daylight hours, offer a unique opportunity to deploy renewable energy system dependent on daylight hours to meet the majority of their electricity demand profile [12]. However, performance assessment of a renewable energy system (RES) for 
a school unit in Turkey showed that the electricity generation solely from renewables was not sufficient to compensate the overall energy demand of the school [13]. Off-grid application of solar and wind power generation with diesel generator and battery backup was found to fully meet the energy demand of a rural school in Morocco at an optimized energy cost of about $1.12 \$ / \mathrm{kWh}$ [14]. Analysis of a grid-connected photovoltaic system for a school in Wellington, New Zealand, reported that the power generated from the system escalated only during the summer time [15]. Another study mainly focused on optimization of several HRES components to compensate for the heating and electricity demand of a school building in South Korea [12]. A study assessing the viability of HRES in a school building in Greece found that the installation could provide mitigation of climate change, resources protection, costs reduction, and energy saving [16].

Techno-economic assessment is widely applied in determining the viability of energy technologies at affordable costs. However, so far the assessments-of HRES configurations, for both grid-connected and off-grid applications, have been mainly restricted to optimal sizing of the system components under local conditions [17-20] and little consideration has been given to optimizing the design of the system altogether, suiting the local conditions (demand profile and renewable supply). This study mainly focuses on the techno-economic feasibility of a grid-connected HRES in compensating the daytime electricity demand for a school building in Banda Aceh, Indonesia, exploring potential options for minimizing its NPC and payback period. The case study utilizes actual data for electricity consumption at the school alongside the seasonal profiles of renewable resource availability. Three HRES configurations are assessed, first two respectively powered by wind + PV and PV only, with no battery backup, and the third configuration powered by PV only with a battery backup. It demonstrates the suitability of an optimized HRES in meeting the electricity demands of the school, predominantly over day time, through direct use of renewable electricity from PV using inverters, avoiding the need for battery storage. The following optimization parameters are used-one, technological performance of the HRES, in terms of their energy output to fulfil the energy deficit; two, economic performance of the HRES, in terms of their net present cost (NPC) and payback periods. NPC includes initial capital expenditure, operation, maintenance and component replacement costs (if any), as well as the revenue from sale to the grid, thereby shortening the payback period. Although the scope of this study is limited to a particular school located in Banda Aceh, Indonesia, the outcome is extendable to similar facilities with predominant daytime electricity demands. 


\section{MATERIALS AND METHODS}

\section{Case Study}

\section{Site description}

A school building in the city center of Banda Aceh in the Aceh province in northwest tip of Indonesia is selected as the case study, located $7 \mathrm{~m}$ above sea level at $5.55^{\circ} \mathrm{N}$ and $95.35^{\circ} \mathrm{E}$ (Figure 1). The site was hit by the devastating tsunami in 2004; over $90 \%$ of the region neighboring the school is electrified, but largely supplied with a mix of diesel and hydro power plants, with approximately $98 \%$ of electricity originating from fossil fuel combustion [7]. However, the region has approximately $4.1 \mathrm{kWh} / \mathrm{m}^{2}$ average daily solar radiation [2], providing huge potential for a gridconnected renewable energy system.

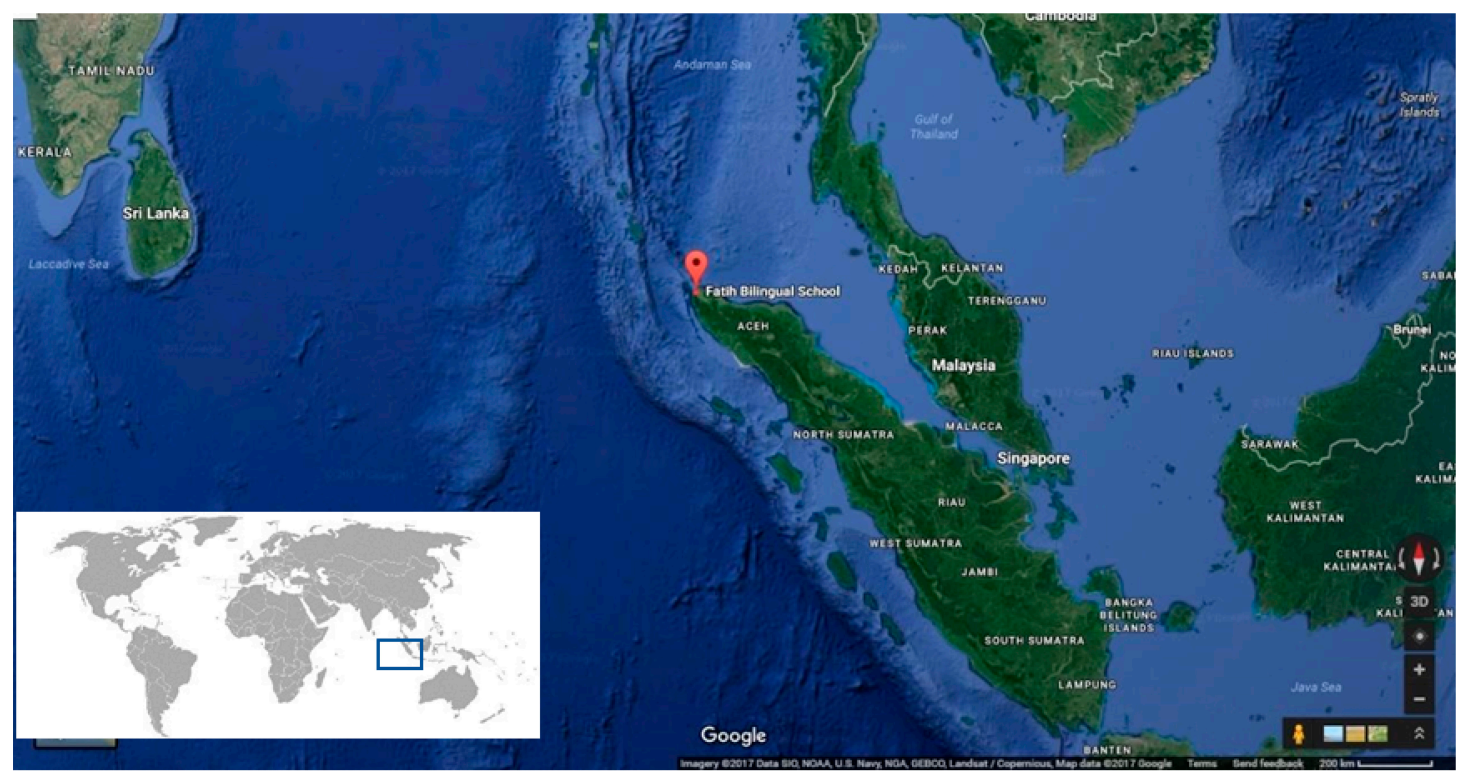

Figure 1. Location of Fatih Bilingual School in Banda Aceh, Indonesia. Shown in the inset is the geographical location of the study site in the global context (Google Maps, 2017).

\section{Electricity demand profile}

The daily electricity consumption profile is generated using the real load profile data for the 2016 academic calendar year of Fatih Bilingual School. Furthermore, the estimation of hourly electricity consumption has been established by comparing the real data of three consecutive monthly electricity bills of the school. Based on this, the following five variants of the daily electricity use profiles have been obtained, accounting for the different activity types and seasonal loads (Figure 2)-Variant 1: General school active days; Variant 2: Weekly meeting and conference; Variant 3: Weekly extra-curricular activity; Variant 4: The seasonal school holidays; Variant 5: Sunday and bank holidays. 


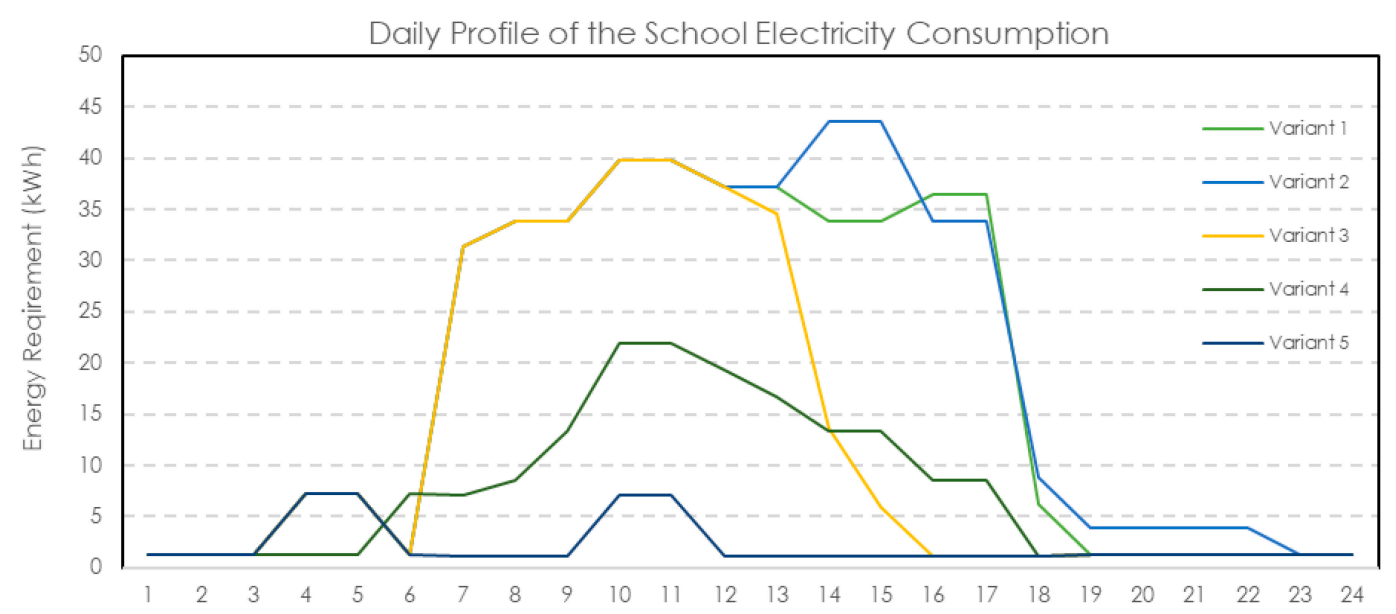

Figure 2. The five variants of the daily electricity consumption profiles of the school.

The operating hours of the school spans from 07:30 to 16:30 during the weekdays and from 07:30 until 14:00 on Saturdays. Furthermore, there is no school activity during the nights. The monthly total energy demand of the school is presented in Figure 3. According to the electricity demand profile, the lowest load requirement is observed in the month of January, June and July. This is attributed to the seasonal holidays over this period when the school is not active. During the rest of the year, the power consumption of the school is generally the same. The minimum and the maximum monthly energy requirement for the teaching process in the school are $6669 \mathrm{kWh}$ and $10,925 \mathrm{kWh}$ respectively. It is assumed the majority of this basal load is attributed to typical HVAC space cooling energy demands over predominantly warmer months in modern buildings in Indonesia [21].

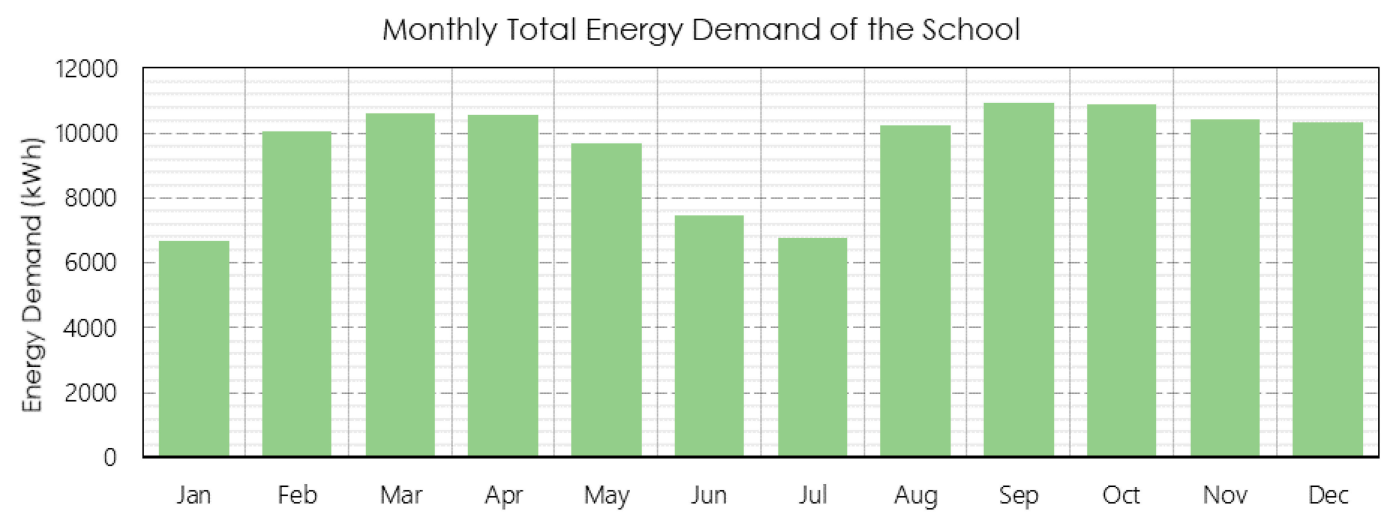

Figure 3. Monthly electricity demand of the school.

\section{Renewable resource availability}

Most of the previous studies have used freely accessible research databases on renewable resources from their respective governmental or national weather databases [12,16,22,23]; the National Institute of Water and Atmospheric (NIWA) research solar-view tool from New Zealand for estimating the solar radiation [15]; the US National Renewable Energy 
Laboratory (NREL) solar radiation and wind resources databases for comparison; RETScreen Expert and Design Builder software data [13]. The following data sources have been used in this study.

Solar irradiance: The Global Horizontal Irradiation (GHI) data in HOMER Pro, based on NREL's typical meteorological year (TMY3) profile derived from the 1961-1990 to 1991-2005 National Solar Radiation Database, has been used to generate the monthly averaged solar irradiance profile for the city of Banda Aceh (based on latitude and longitude) (Figure 4) [24]. GHI is considered appropriate for estimating PV power outputs as it is the sum of beam radiation (also called direct normal irradiance or DNI), diffuse irradiance, and ground-reflected radiation. Based on the data, the location is found to have a fairly constant solar irradiance profile throughout the year, which is owing to its location near the equator. However, there is slight decrease in the magnitude of solar irradiance in the last 3 months of the year, attributed to the onset of the rainy period over these months.

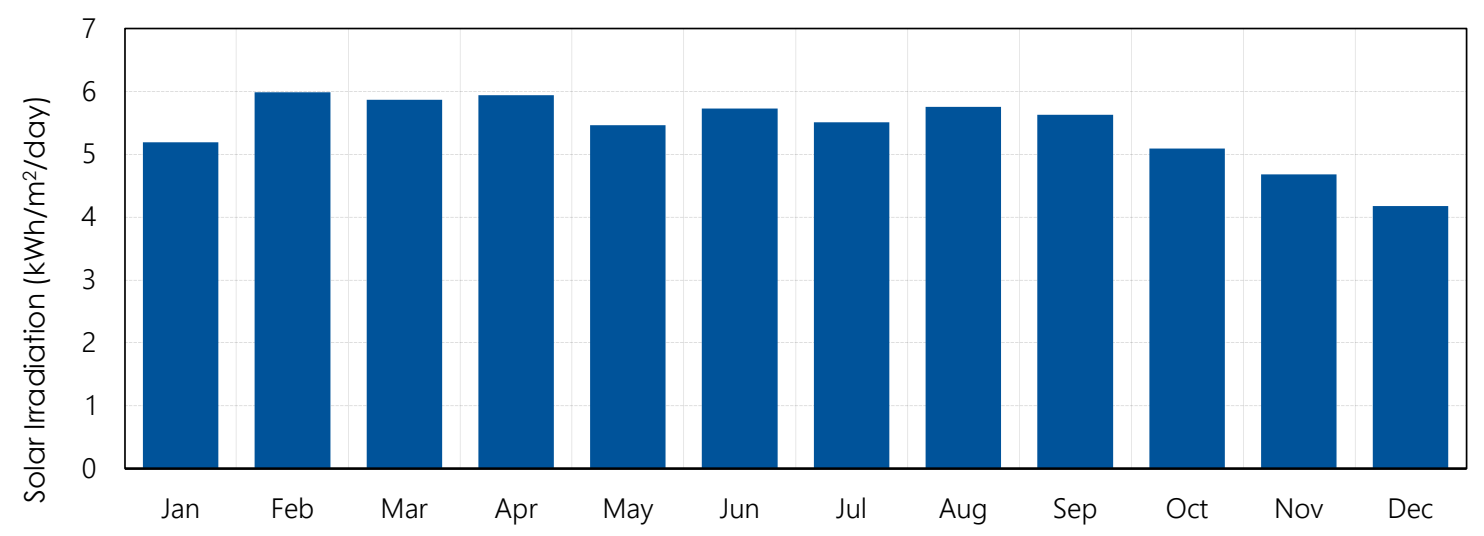

Figure 4. Solar irradiance profile in Banda Aceh (source: Homer Pro [24]).

Wind speed: The monthly average wind speed profile at the school location has been estimated using the hourly wind speed data obtained from the NREL database for the city of Banda Aceh (Figure 5).

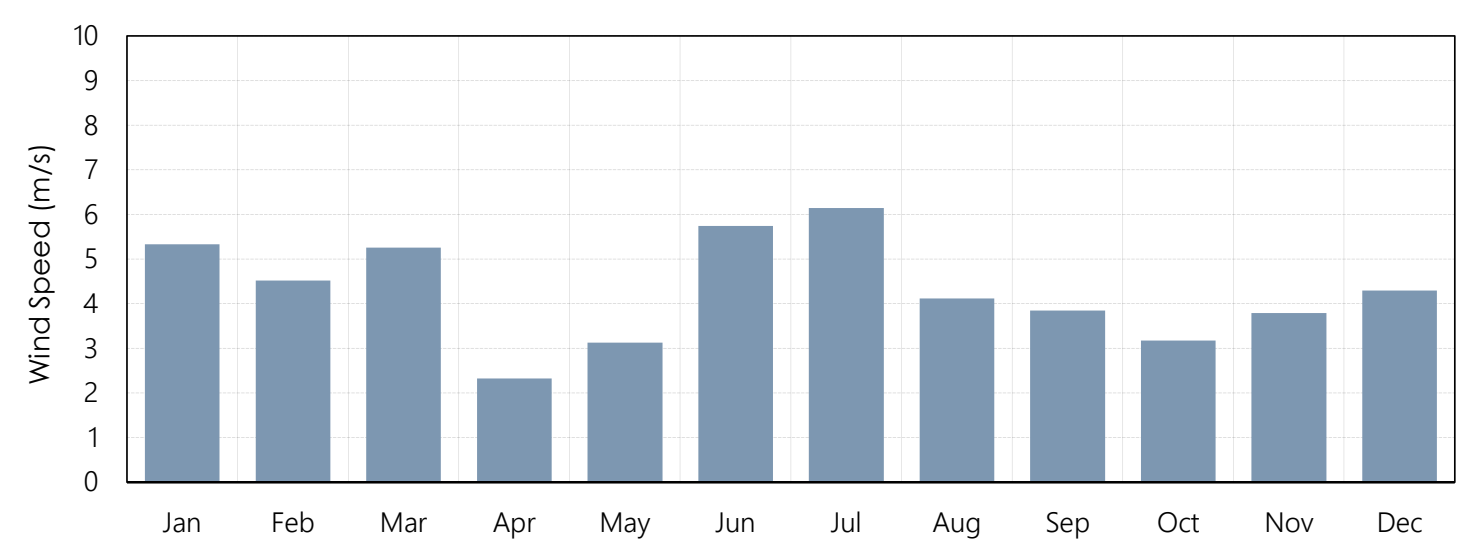

Figure 5. Wind profile in Banda Aceh (source: Homer Pro [24]). 


\section{Energy system component specification and pricing}

The hardware spec for the different HRES components used in this study and their initial capital costs are shown in Table 2. The lifespan of the energy generating hardware components (PV and wind turbine) is assumed to be 20 years that of the inverter as 15 years and the battery life is assumed to be 10 years. The selected PV module has maximum power of $250 \mathrm{~W}$, efficiency of $15 \%$ and the annual operational \& maintenance cost of US $\$ 100$ [25]. A relatively smaller size single wind turbine is considered for installation at the school with the maximum power output of $10 \mathrm{~kW}$, rotor diameter and tower height of $5.5 \mathrm{~m}$ and $15 \mathrm{~m}$, respectively [26].

Table 2. Summary of HRES component specification, capacity and pricing.

\begin{tabular}{|c|c|c|c|c|}
\hline Category & Solar PV & Wind turbine & $\begin{array}{l}\text { Grid-connected } \\
\text { Solar Inverter }\end{array}$ & Battery \\
\hline Brand & Surya Greentek [25] & Evance R9000 [26] & iMars M Series [27] & VRLA Aki Kering Solar Cell [28] \\
\hline \multirow[t]{5}{*}{ Capacity } & $250 \mathrm{~W}$ & $10 \mathrm{~kW}$ & $5 \mathrm{~kW}$ & $12 \mathrm{~V}, 120 \mathrm{Ah}$ \\
\hline & Panel dimensions & Rotor diameter: $5.5 \mathrm{~m}$ & & \\
\hline & Length: $1.64 \mathrm{~m}$ & Hub height: 15 m & & \\
\hline & Breadth: $0.99 \mathrm{~m}$ & Cut-in speed: $2.5 \mathrm{~ms}^{-1}$ & & \\
\hline & Width: $0.04 \mathrm{~m}$ & Cut-off speed: $25 \mathrm{~ms}^{-1}$ & & \\
\hline Efficiency (\%) & 15 & - & 95 & 1800 cycles, DOD: $30 \%$ \\
\hline Lifetime (years) & 20 & 20 & 15 & 5 \\
\hline Unit price per kW (US\$) & 840 & 40099 & 165 & 140/battery \\
\hline O\&M cost (US\$/year) & 100 & 200 & - & 10 \\
\hline Replacement cost (US\$) & 840 & 40,099 & 165 & 140/battery \\
\hline
\end{tabular}

All the solar panels have been assumed to be installed on building rooftops facing due north and tilted at $5^{\circ}$ to the horizontal to allow for draining of rain water. The key consideration in determining appropriate rooftop location for citing the solar panels is their non-obstruction from shadows throughout the daylight period. It was considered that only one wind turbine could be installed, given the small fetch offered by the builtup space in the school premises.

\section{Energy pricing}

The Feed-in-tariff introduced by the Minister of Energy and Mineral Resources (MEMR) vide regulation No. 50/2017 on power purchase for a range of renewable energy generator is applied to this study. Accordingly, the selling price of electricity from the grid has been set to the national average production cost in Indonesia (US\$ 0.12 per $\mathrm{kWh}$ ) [7]. Therefore, the price of buying electricity from the grid is set to be equal to the selling price. In other words, the excess power generated by HRES in the school is assumed to be sold to the grid at the same unit price of US\$ 0.12 per $\mathrm{kWh}$. 


\section{Modelling Methods}

The Hybrid Optimization of Multiple Energy Resources (HOMER Pro ${ }^{\circledR}$ ) model, developed by the National Renewable Energy Laboratory [29], is used to assess the techno-economic feasibility of the proposed HRES to be installed at the school. The modelling method followed the suggested approach in the literature [22,30,31], requiring several input parameters in terms of the wind and solar resources, energy demand, system components, and the specified cost of each component.

(a)

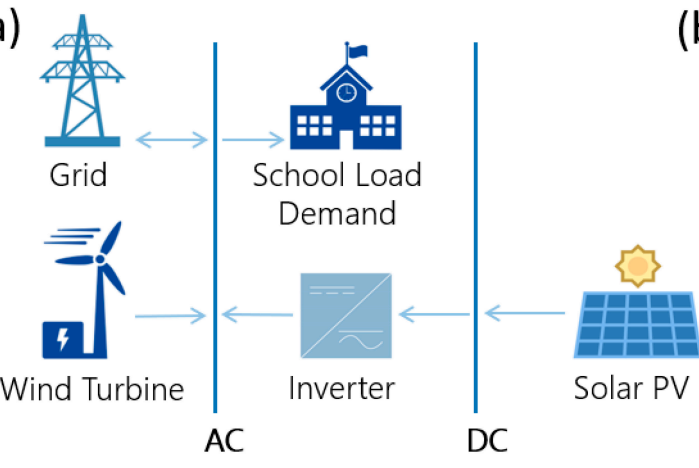

(c)

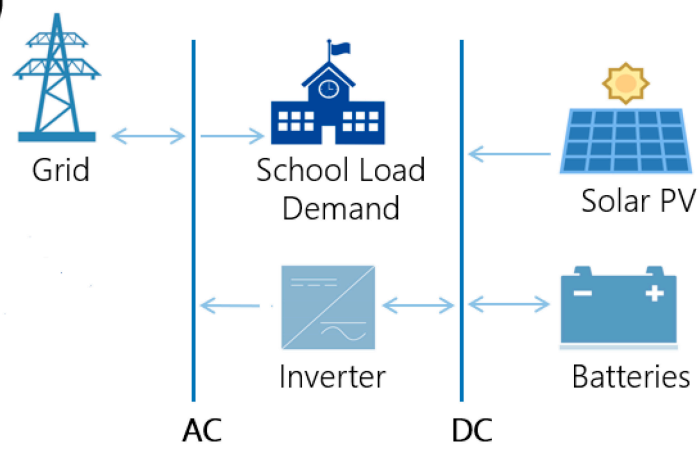

(b)

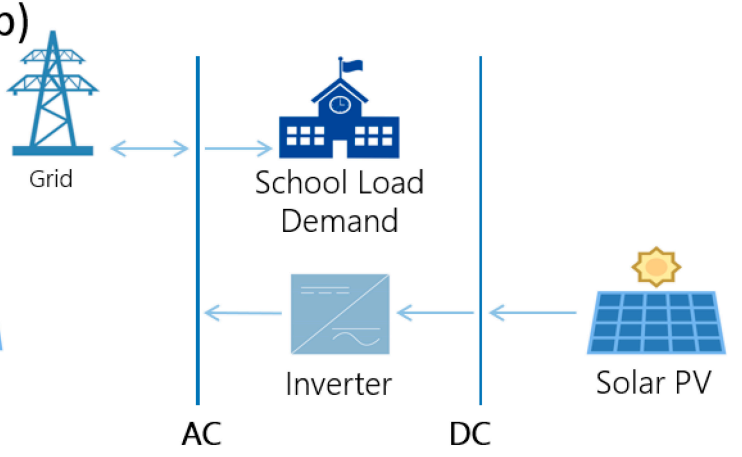

Figure 6. Schematic of the modelled configuration-(a) Scenario I; (b) Scenario II; (c) Scenario III.

\section{HRES model scenarios}

The following three scenarios, each with unique sizing of the HRES components, have been modelled to evaluate their techno-economic performances. Scenario I-Figure 6a shows the components of the gridconnected HRES, comprising of Solar PV, Wind Turbine, and Inverter. This kind of configuration is expected to generate additional revenue through sale of the excess energy produced from renewables to the grid. The only disadvantage of this design is it has no backup to cover the power shortage, in case of loss of supply from renewable generation. Scenario II-Figure $6 \mathrm{~b}$ shows the configuration for this scenario, comprising of Solar PV and Inverter only. It is based on the premise that the wind speed in the particular location is relatively insufficient to achieve the rated power output of the wind turbine. Scenario III-Figure 6c shows the configuration for this scenario, comprising of Solar PV, Inverter and Battery as an additional backup. In this system the power demand can be 
compensated by the power stored in the battery when the grid is unable to provide the electricity. Moreover, the excess energy from the renewables can also be sold back to the grid when the battery is fully charged. This is specifically suitable for utilizing the battery backup in meeting the unmet loads. The drawback for this configuration is that the total cost is expected to be relatively high.

\section{Techno-economic optimization}

For each of the three scenarios, the optimum configuration, the size of the solar PV area and the number of wind turbines are determined using the optimization features of the HOMER Pro ${ }^{\circledR}$ software. The minimum and the maximum bounds for each component sizing were assigned in HOMER Optimizer with a Search Space, and the optimized configurations was selected on the basis of the lowest net present cost following [32]. The wind turbine feature was limited to a single unit owing to the restriction on the space available, as discussed earlier. The technological performance of the HRES in terms of their energy output to fulfil the energy deficit (and where applicable, to surpass in case of selling electricity back to the grid), and the economic performance (in terms of the HRES NPC and payback), have been respectively considered the two key optimization parameters.

\section{RESULTS AND DISCUSSION}

\section{Scenario Analysis}

Each of the three modelled scenarios present unique attributes in terms of their optimum configuration size of the renewable energy technologies affecting their feasibility and also the total cost of the system over their 20year operational life. The priority of this exercise is to find the configuration with the lowest total cost and the fastest payback period. Figure 7a-c respectively shows weekly patterns of the electricity demandsupply profiles for the three scenarios. In each plot, the upper line shows the supply from the renewable generation and the lower line represents the load profile, generated in HOMER using real usage data for a typical week from Monday to Sunday (between 00:00-24:00).

Scenario I-The simulated optimal configuration of RES design for this scenario comprises of $105 \mathrm{~kW}$ of Solar PV, a single $10 \mathrm{~kW}$ WT, and $66 \mathrm{~kW}$ Inverter. The renewable energy generation patterns for this scenario oscillates with daily peaks around noon and troughs around sunrise and sunset, with further energy generation in the late night and early hours (Figure 7a). The latter is mainly contributed from wind turbine. However, the early morning school electricity demand remain largely unmet, owing to shortfall in renewable generation from both solar and wind (Figure 7a), requiring high level of grid electricity purchase. By using this configuration, the initial capital cost (ICC) for the deployment and the NPC of this design was estimated to be US\$ 91,874 and US\$ $-242,454$ respectively. The negative sign at the NPC value indicates that in the 20th 
year there will be an income of that amount from the sale of electricity back into the grid. Additionally, the payback time of this design was estimated to be 9 years. In this configuration, $88.4 \%$ of the school electricity demand is estimated to be compensated by the power from the PV. Additionally, the power from WT and the grid contributed only $7.81 \%$ and $3.77 \%$ of the load respectively. The simulation showed that the power produced by WT is inferior to that by PV, which is acceptable for the location, based on the availability of low wind speeds. This configuration is advantageous to be deployed in the school setting as it appears to meet the electricity requirements for the school during the peak operation time. Figure $7 \mathrm{a}$ shows that most of the load can be compensated by the renewable power (upper line) generated from the optimal configuration for this scenario (only $2.82 \%$ of the generated power were consumed by the school and the rest $97.2 \%$ were sold back to the grid). This corroborates the findings reported in a previous study [12], which stated that the RES installation at a school is suitable in accordance of its energy demand profile and condition of the location.

Scenario II-This scenario maximizes the potential for solar generation while reduces the capital expenditure by removing the deployment of wind turbine and battery backup. However, as expected, the HRES power output of this scenario is relatively lower than the previous scenario and restricted to daylight hours (meeting $94.5 \%$ of the electricity demand, with the $5.50 \%$ fulfilled via grid purchases). Figure $7 \mathrm{~b}$ shows the typical weekly energy demand profile of the school and the total electricity supply from the optimal configuration for this scenario. On an average, the school consumed around $30 \%$ of the total power generated and the remaining $70 \%$ was sold back to the grid. However, as in case of Scenario I, some portion of the energy requirement during early morning hours could not be met from the renewable generation when the solar irradiation is not quite intense. Hence, maintaining grid connectivity was considered essential to avoid any loss of supply during these hours. The outcome of the estimation showed that the amount of energy which could be sold back to the grid was directly proportional to the inverter output power.

Scenario III-In this scenario the deficit power could be either drawn from the batteries or bought from the grid. Similar to the previous two scenarios, the power from renewables could not fulfil the electricity demand of the school in the early morning hours. However, the reliance on the grid supply was compensated by drawing the deficit power from the battery storage, leading to minimal grid electricity purchase for this scenario. Figure 7c shows how the battery system accommodates the morning time load, indicated by dip in the Battery energy (top black line). The use of battery was observed during the week-days and Saturdays. However, due to the low electricity demand on Sundays, the batteries were noted to be fully charged and the excess power produced by the renewables were sold to the grid. 
(a)

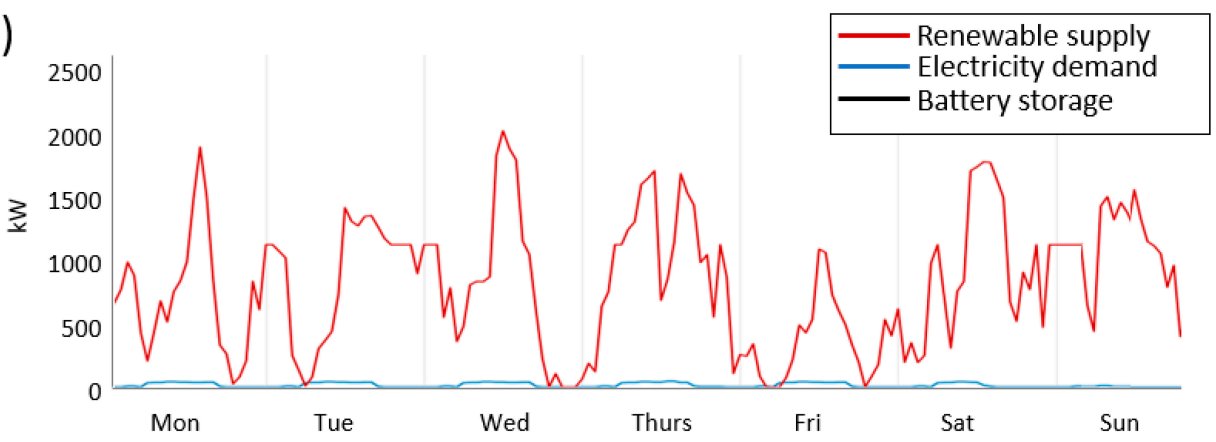

(b)

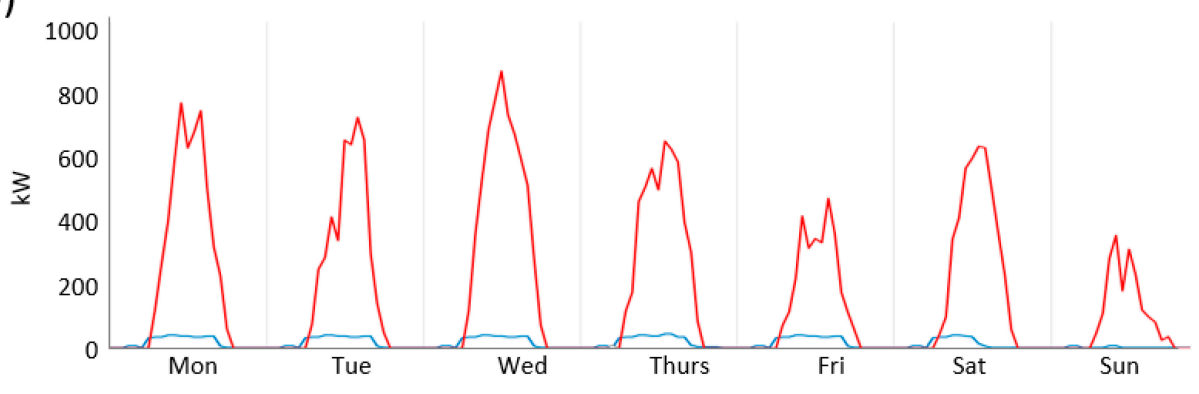

(c)

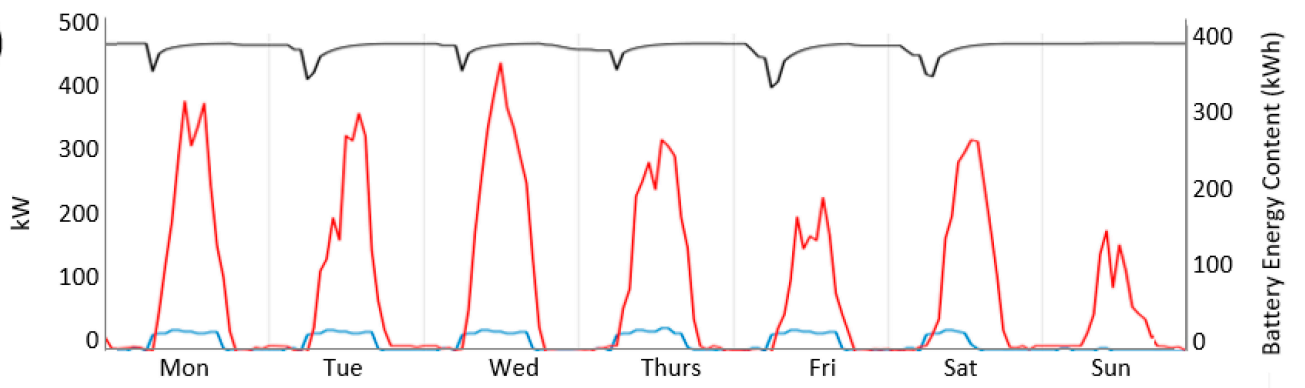

Figure 7. Weekly patterns of the electricity demand-supply profiles for the three scenarios (upper line: renewable generation; lower line: load profile)—(a) Scenario I; (b) Scenario II; (c) Scenario III.

\section{Cost efficiency}

The initial capital costs, NPC values and payback periods for the optimized HRES configurations to meet the annual electrical load of the school of 114,654 $\mathrm{kWh}$ for the three scenarios, and the corresponding annual energy flows to the grid (purchase and sell), are shown in Table 3. It shows the tradeoffs between the costs and energy provision from different scenarios. Scenario I shows the highest capital costs, which is expected due to inclusion of wind turbine, although this design had lower number of solar panels. Despite having the highest amount of energy sale to the grid, this scenario still has considerable grid purchase of electricity owing to lack of back up for unmet loads during early morning school operations (Figure 7a). As expected, scenario II has the least payback period of 4 years, owing to the relatively lower initial capital costs of the hardware and considerable sale of electricity to the grid. Scenario 3 appears least favorable in terms of NPC, which is mainly attributed to high level of battery replacement and operation and maintenance costs. 
Table 3. Optimized techno-economic performance outputs for the three scenarios.

\begin{tabular}{|c|c|c|c|c|c|c|c|c|c|}
\hline Scenarios & $\begin{array}{c}\text { Solar PV } \\
\text { Capacity } \\
(\mathrm{kW})\end{array}$ & $\begin{array}{c}\text { Wind } \\
\text { Turbine } \\
\text { Capacity } \\
\text { (kW) }\end{array}$ & $\begin{array}{c}\text { No. of } 12 \mathrm{~V} \\
\text { Batteries } \\
\text { (units) }\end{array}$ & $\begin{array}{c}\text { Inverter } \\
\text { Capacity } \\
\text { (kW) }\end{array}$ & $\begin{array}{c}\text { Energy } \\
\text { Purchased } \\
\text { (kWh/year) }\end{array}$ & $\begin{array}{c}\text { Energy } \\
\text { Sold to } \\
\text { Grid } \\
\text { (kWh/year) } \\
\end{array}$ & $\begin{array}{c}\text { Initial Capital } \\
\text { Cost } \\
\text { (US\$) }\end{array}$ & $\begin{array}{c}\text { Total NPC } \\
\text { (US\$) }\end{array}$ & $\begin{array}{c}\text { Payback } \\
\text { period } \\
\text { (year) }\end{array}$ \\
\hline Scenario I & 105 & 10 & - & 66 & 16,872 & 318,414 & 91,874 & $-242,454$ & 9 \\
\hline Scenario II & 245 & - & - & 184 & 22,852 & 289,314 & 51,686 & $-138,017$ & 4 \\
\hline Scenario III & 245 & - & 80 & 55 & 23 & 308,783 & 62,886 & $-67,502$ & 6 \\
\hline
\end{tabular}

It is noteworthy, the study mainly focused on renewable energy provision to meet the existing school energy demands, without considering further modification of the building design and passive cooling strategies, e.g., HVAC efficiency enhancement and/or cooling capacity enhancement through inclusion of innovative PV-thermal technologies, which are still undergoing R\&D improvements and thereby lacking cost-competitiveness [21].

\section{CONCLUSIONS}

This study demonstrates the strength of techno-economic assessment as a decision support in developing hybrid renewable energy system (HRES) utilizing local renewable resources to fulfil the daytime electricity demand for a school in northwest Indonesia. Three different scenarios are developed for optimizing a grid-connected HRES by maximizing the renewable energy generation potential while minimizing the economic impact using a combination of NPC and payback period, the latter in terms of revenue generation from sale of electricity to the grid. Scenario II, comprising of Solar PV and Inverter only, is found to be the most feasible and cost-effective HRES, with the optimized configuration of $245 \mathrm{~kW}$ PV and $184 \mathrm{~kW}$ inverter having the lowest initial capital cost of US\$ 51,686 and the payback time of 4 years. However, owing to limited availability of solar irradiance in the early morning hours and no battery storage backup or wind generation, the electricity demand during this period could not be fulfilled by the renewables alone. Nevertheless, the operating time of the school suits the energy production profile of this optimized HRES configuration, owing to the majority of school operations involving electricity consumption predominantly during daylight hours. The proposed optimized configuration can serve electricity requirements of similar facilities with daytime demands, bypassing the need for expensive battery backups.

\section{DATA AVAILABILITY}

All data generated from the study are provided in the Figures presented. 


\section{AUTHOR CONTRIBUTIONS}

BI conducted the initial scoping of the grid-integrated renewable energy system and evaluated the performance under localized setting using inventoried data on relevant renewable resources. AT supervised the overall progression of this research and supported in interpretation of the results and the final write of the results and discussions based on the analysis.

\section{CONFLICTS OF INTEREST}

The authors declare that there is no conflict of interest.

\section{ACKNOWLEDGMENTS}

The first author acknowledges the support of the government of Aceh Province, northwest Indonesia in conducting this research. Acknowledgements are also due for the invaluable contributions from the teachers and staff of Fatih Bilingual School in Banda Aceh for supplying data to complete this study.

\section{REFERENCES}

1. Dutu R. Challenges and policies in Indonesia's energy sector. Energy Policy. 2016;98:513-9. https://doi.org/10.1016/j.enpol.2016.09.009

2. KESDM. Strategic Planning 2015-19: National Energy Consumption at Each Sector. Jakarta (Indonesia): KESDM; 2015.

3. REN21. Renewables 2019 Global Status Report. Paris (France): REN21; 2019. Available from: https://wedocs.unep.org/bitstream/handle/20.500.11822/ 28496/REN2019.pdf?sequence=1\&isAllowed=y\%0Ahttp://www.ren21.net/citie s/wp-content/uploads/2019/05/REC-GSR-Low-Res.pdf. Accessed 2019 Dec 29.

4. Erdiwansyah, Mamat R, Sani MSM, Sudhakar K. Renewable energy in Southeast Asia: Policies and recommendations. Sci Total Environ. 2019;670:1095-102. https://doi.org/10.1016/j.scitotenv.2019.03.273

5. Ismail MS, Moghavvemi M, Mahlia TMI, Muttaqi KM, Moghavvemi S. Effective utilization of excess energy in standalone hybrid renewable energy systems for improving comfort ability and reducing cost of energy: A review and analysis. Renew Sustain Energy Rev. 2015;42:726-34. https://doi.org/10.1016/j.rser.2014.10.051

6. Kjellstrom T, Briggs D, Freyberg C, Lemke B, Otto M, Hyatt O. Heat, Human Performance, and Occupational Health: A Key Issue for the Assessment of Global Climate Change Impacts. Ann Rev Public Health. 2016;37:97-112. https://doi.org/10.1146/annurev-publhealth-032315-021740

7. PT PLN (Persero). Statistik PLN 2017. Jakarta (Indonesia): PT PLN (Persero); 2018.

8. EBTKE. Strategic Plan of 2015-2019. Jakarta (Indonesia): EBTKL; 2015.

9. NEC. Indonesia Energy Outlook. Jakarta (Indonesia): NEC; 2016.

10. ESDM P. Perkembangan Penyediaan dan Pemanfaatan Migas Batubara Energi Baru Terbarukan dan Listrik. Jakarta (Indonesia): ESDM P; 2015. 
11. Gajbhiye P, Suhane P. Optimal Sizing of Stand-Alone Hybrid Solar/Wind/Battery/Diesel Energy System. Int J Innovative Res Dev. 2015;4(4):93-8.

12. Kim J, Kim EJ. Simplified method of optimal sizing of a renewable energy hybrid system for schools. Sustainability. 2016;8:1134. https://doi.org/10.3390/su8111134

13. Bilir L, Yildirim N. Photovoltaic system assessment for a school building. Int J Hydrogen Energy. 2017;42:17856-68. https://doi.org/10.1016/j.ijhydene.2017.02.122

14. Lamnadi M, Trihi M, Boulezhar A. Study of a hybrid renewable energy system for a rural school in Tagzirt, Morocco. In: 2016 International Renewable and Sustainable Energy Conference (IRSEC); 2016 Nov 14-17; Marrakech, Morocco. Piscataway (NJ, US): IEEE; $2017 . \quad$ p. 381-6. https://doi.org/10.1109/IRSEC.2016.7984079

15. Emmanuel M, Akinyele D, Rayudu R. Techno-economic analysis of a $10 \mathrm{kWp}$ utility interactive photovoltaic system at Maungaraki school, Wellington, New Zealand. Energy. 2017;120:573-83. https://doi.org/10.1016/j.energy.2016.11.107

16. Economou A. Photovoltaic systems in school units of Greece and their consequences. Renew Sustain Energy Rev. 2011;15:881-5. https://doi.org/10.1016/j.rser.2010.09.028

17. Kaabeche A, Ibtiouen R. Techno-economic optimization of hybrid photovoltaic/wind/diesel/battery generation in a stand-alone power system. Sol Energy. 2014;103:171-82. https://doi.org/10.1016/j.solener.2014.02.017

18. Hiendro A, Kurnianto R, Rajagukguk M, Simanjuntak YM, Junaidi. Technoeconomic analysis of photovoltaic/wind hybrid system for onshore/remote area in Indonesia. Energy. 2013;59:652-7. https://doi.org/10.1016/j.energy.2013.06.005

19. Shaahid SM, Elhadidy MA. Technical and economic assessment of gridindependent hybrid photovoltaic-diesel-battery power systems for commercial loads in desert environments. Renew Sustain Energy Rev. 2007;11:1794-810. https://doi.org/10.1016/j.rser.2006.03.001

20. Kolhe ML, Ranaweera KMIU, Gunawardana AGBS. Techno-economic sizing of off-grid hybrid renewable energy system for rural electrification in Sri Lanka. Sustain Energy Technol Assessments. 2015;11:53-64. https://doi.org/10.1016/j.seta.2015.03.008

21. Herrando M, Pantaleo AM, Wang K, Markides CN. Solar combined cooling, heating and power systems based on hybrid PVT, PV or solar-thermal collectors for building applications. Renew Energy. 2019;143:637-47. https://doi.org/10.1016/j.renene.2019.05.004

22. Shezan SA, Julai S, Kibria MA, Ullah KR, Saidur R, Chong WT, et al. Performance analysis of an off-grid wind-PV (photovoltaic)-diesel-battery hybrid energy system feasible for remote areas. J Clean Prod. 2016;125:12132. https://doi.org/10.1016/j.jclepro.2016.03.014

23. Mudasser M, Yiridoe EK, Corscadden K. Cost-benefit analysis of gridconnected wind-biogas hybrid energy production, by turbine capacity and site. Renew Energy. 
24. HOMER. Finding Data to Run HOMER Pro 2017. Available from: https://www.homerenergy.com/products/pro/docs/latest/finding data to run homer.html. Accessed 2017 Apr 20.

25. Surya Greentek. SOLAR panel - Surya Greentek 250 WP 2017. Available from: https://www.bukalapak.com/p/elektronik/lampu-alat-penerangan/5atypkjual-solar-panel-panel-surya-greentek-250wp. Accessed 2017 Jun 10.

26. Sustainable Energy Systems Ltd. 5kW Britwind (Formerly Evance) R9000 Wind turbine 2017. Available from: https://www.sustainableenergysystems.co.uk/case-studies/2-x-britwindr9000-5kw-installation/. Accessed 2017 Jun 15.

27. IMars. iMars M Series solar inverter 2017. Available from: http://www.invtsolar.com/uploadfiles/2019/02/INVT MG 0.75-6KW user manual.pdf. Accessed 2017 May 10.

28. Varla Aki. VRLA Aki Kering Solar Cell 2017. Available from: https://www.bukalapak.com/p/elektronik/baterai-681/80v4az-jual-batteryvrla-aki-kering-solar-cell-12v-120ah. Accessed 2017 May 20.

29. HOMER. Hybrid Optimization of Multiple Energy Resources (HOMER®) Pro Version 3.9 Program 2017. Boulder (CO, US): HOMER; 2017.

30. Ramli MAM, Hiendro A, Sedraoui K, Twaha S. Optimal sizing of gridconnected photovoltaic energy system in Saudi Arabia. Renew Energy. 2015;75:489-95. https://doi.org/10.1016/j.renene.2014.10.028

31. Kolhe M, Ranaweera KMIU, Gunawardana AGBS. Techno-economic optimum sizing of hybrid renewable energy system. In: IECON 2013-39th Annual Conference of the IEEE Industrial Electronics Society; 2013 Nov 10-13; Vienna, Austria. Piscataway (NJ, US): IEEE; $2014 . \quad$ p. 1898-903. https://doi.org/10.1109/IECON.2013.6699421

32. Bahramara S, Moghaddam MP, Haghifam MR. Optimal planning of hybrid renewable energy systems using HOMER: A review. Renew Sustain Energy Rev. 2016;62:609-20. https://doi.org/10.1016/j.rser.2016.05.039

How to cite this article:

Illiandi B, Tiwary A. Techno-Economic Feasibility of a Grid-Connected Hybrid Renewable Energy System for a School in North-West Indonesia. J Sustain Res. 2020;2(2):e200015. https://doi.org/10.20900/jsr20200015 